\section{Australian Journal of \\ Crop Science}

AJCS

ISSN:1835-2707

AJCS 13(12):2053-2061 (2019)

doi: 10.21475/ajcs.19.13.12.p2070

\title{
Physiological responses and post-stress recovery in field-grown maize exposed to high temperatures at flowering
}

\author{
Nicolás Neiff* ${ }^{1}$, Edmundo L. Ploschuk ${ }^{2}$, Oscar R. Valentinuz ${ }^{3}$, Fernando H. Andrade ${ }^{4}$ \\ ${ }^{1}$ CONICET and Universidad Nacional del Nordeste, Facultad de Ciencias Agrarias, Departamento de Producción \\ Vegetal, Corrientes (3400), Argentina \\ ${ }^{2}$ Universidad de Buenos Aires, Facultad de Agronomía, Cátedra de Cultivos Industriales. Av. San Martín 4453 \\ (1417), Buenos Aires, Argentina \\ ${ }^{3}$ Instituto Nacional de Tecnología Agropecuaria (INTA), Paraná (3100), Argentina \\ ${ }^{4}$ CONICET, Unidad Integrada Balcarce and Instituto Nacional de Tecnología Agropecuaria (INTA), Balcarce (7620), \\ Argentina
}

*Corresponding author: nneiff@icloud.com

Abstract

Heat stress affects physiological traits and biomass production in major crops, including maize. We researched the responses of maximum efficiency of photosystem II $\left(\mathrm{F}_{\mathrm{v}} / \mathrm{F}_{\mathrm{m}}\right)$, relative cell injury $(\mathrm{RCl})$, stomatal conductance $\left(g_{s}\right)$, internal $\mathrm{CO}_{2}$ concentration $\left(\mathrm{C}_{\mathrm{i}}\right)$, leaf photosynthesis (CER), and crop growth rate (CGR) in two maize cultivars exposed to high temperatures around silking (R1) under field conditions. Temperature regimes (i.e. control and heat) were performed during the pre-silking $(-15 d$ R1 to R1) and post-silking $(R 1+2 d$ to $R 1+17 d)$ periods. In the heat treatments, polyethylene shelters were used in order to increase daytime temperatures around midday (from 10 A.M. to 2 P.M.) during each period (i.e., pre- and post-silking). In the control treatments, the shelters remained open during the entire growing season. Gas exchange variables, $F_{v} / F_{m}$ and relative cell injury $(R C l)$ were measured on ear leaves. CGR was estimated based on biomass samples. CER and $F_{v} / F_{m}$ presented maximum reductions at the end of the daytime heating. However, $30 \mathrm{~min}$ after the shelters were reopened, $F_{v} / F_{m}$ of heated leaves reached values similar to controls, which were closely linked to CER recoveries. $\mathrm{RCl}$ was negatively associated with $\mathrm{F}_{\mathrm{v}} / \mathrm{F}_{\mathrm{m}}$, and cell injury increased gradually as heating continued. $C_{i}$ was unaffected by heat treatment, indicating that $g_{s}$ was not the primary cause of CER reduction. Heat stress decreased CGR, and the reduction was positively associated with CER and $F_{v} / F_{m}$ in both heating periods. We attempted to scale from cell to crop level and identify some physiological traits that could be helpful in breeding programs for heat stress tolerance.

Keywords: Biomass production; climate change; heat stress; photosynthesis; Zea mays.

Abbreviations: $\mathrm{CER}$ _carbon exchange rate; $\mathrm{C}_{\mathrm{i}}$ internal $\mathrm{CO}_{2}$ concentration; $\mathrm{CGR}$ _crop growth rate; $\mathrm{CMS}$ _cell membrane stability; CUL_cultivar; E_leaf transpiration; $F_{v} / F_{m \_}$maximum efficiency of photosystem II; $g_{s \_}$stomatal conductance; $L T$ leaf temperature; Md_measurement day; RCl_relative cell injury; TR_temperature regime; Tr_tropical maize cultivar; Tx_tropical $\times$ temperate maize cultivar.

\section{Introduction}

Agricultural production, and thus global food security, is directly affected by global warming (Fischer et al., 2005, Schmidhuber and Tubiello, 2007, Ainsworth and Ort, 2010). It has been projected that, by 2050 , global food production should increase $70 \%$ in relation to that of 2010 . This must be achieved in a climate change scenario that tends to escalate the problems of food insecurity (Varshney et al., 2010). In tropical and subtropical climates, heat stress may become a major limiting factor for field crop production (Wahid et al., 2007). This is particularly relevant for crops such as maize (Zea mays L.), which accounts for a high percentage of total cereal production worldwide.

Heat stress can produce metabolic limitations such as ionleakage, as indicated by relative cell injury $(\mathrm{RCl})$ (Saadalla et al., 1990, Shanahan et al., 1990, Howarth et al., 1991), and decreases photosystem II (PSII) activity (Sinsawat et al., 2004, Ergo et al., 2018). Inactivation of PSII by high temperature is generally not reversible (Karim et al., 1999, Sinsawat et al., 2004); however, it depends on several factors, such as growing temperatures, acclimation factors, intensity, and duration of heat stress. Hence, the recovery of the maximum efficiency of PSII $\left(F_{v} / F_{m}\right)$ and leaf photosynthesis after heat stress deserves special attention. Recently, Neiff et al. (2016) found leaf photosynthesis recovery within one hour after heat stress. However, leaf photosynthesis recovery after heat stress and the related physiological traits remain poorly understood under field conditions. 
It is well known that heat stress involves decreases in leaf gas exchange variables. Photosynthesis declines as a consequence of the photo-inhibition of PSII activity, which has been shown to be the most thermally labile component of the electron transport chain (Quinn and Williams, 1985, Havaux et al., 1991, Havaux and Tardy, 1996, Havaux et al., 1996). Furthermore, there is evidence that heat stress also modifies stomatal conductance (Heckathorn et al., 1998, Bunce, 2005). Stomatal limitations, however, could only be considered when the internal $\mathrm{CO}_{2}$ concentration is reduced (Zhou et al., 2007). There is not enough evidence to distinguish between stomatal and non-stomatal limitations responsible for the inhibition of photosynthesis under heat stress.

A sufficiently high photosynthetic rate and radiation use efficiency were crucial for maintaining crop growth rates under high temperatures (Rattalino Edreira et al., 2012, Neiff et al., 2016). In this study, we attempt to "scale up" different levels of organization that could be involved in biomass production around flowering in maize. The main goal of this research is to analyze, for two maize cultivars under field conditions, the effect of high temperatures around flowering on gas exchange variables, cell membrane stability, maximum efficiency of PSII and crop growth rate, including post-stress recovery of some physiological traits. The proposed hypotheses are: i) the recovery of leaf photosynthesis rate is directly related to the recovery of PSII activity; ii) photosynthesis reduction produced during heat stress under field conditions is mainly determined by non-stomatal factors; and iii) crop growth rate at pre- and post-silking is directly associated with $F_{v} / F_{m}$ and $C E R$, and inversely associated with $\mathrm{RCl}$.

\section{Results}

High temperature effects on physiological traits measured on ear leaves

Temperature regimes (TR) significantly affected $(p<0.01)$ leaf temperature (LT), stomatal conductance $\left(g_{s}\right)$, leaf transpiration (E) and leaf photosynthesis rate (CER) in both cultivars under saturating irradiances (Table 1 and Fig. 1). As a result of artificial heating, differences between temperature regimes were significant as indicated by the LT records measured at ear level (Table 1). Average temperature at ear level during heating was increased up to $4.3^{\circ} \mathrm{C}$ during $\mathrm{H} 1$ and $4.7^{\circ} \mathrm{C}$ during $\mathrm{H} 2$ on heated plots, when compared with control plots (additional data in Table 1 and Fig.1; Neiff et al., 2016).

Four hours after the start of the daytime heating, $F_{v} / F_{m}$ was reduced to 0.627 and 0.652 (averaged across days and cultivars) for $\mathrm{H} 1$ and $\mathrm{H} 2$, respectively (Fig. 1). However, no significant differences were found between cultivars for this trait $(p>0.05)$. Surprisingly, $F_{v} / F_{m}$ presented a fast recovery 30 min after the end of the daytime heating (94.5 and 93.9\% for pre- and post-silking, respectively; averaged across days and cultivars). In fact, no significant differences in $F_{v} / F_{m}$ were found between control and heated plots at dawn of the next day (data not shown).

As a result of heat stress, CER measured at the end of the daytime heating showed a reduction when compared to the control treatment in both cultivars $(\mathrm{H} 1$ : -29.0 and $-35.8 \%$ for $\operatorname{Tr}$ and $\mathrm{Tx}$, respectively; and $\mathrm{H} 2$ : -23.0 and $-30.7 \%$ ). Cultivars subjected to high temperatures seemed to have fully recovered $60 \mathrm{~min}$ after the daytime heating, as indicated by CER levels (Fig. 1). As expected, major decreases in $F_{v} / F_{m}$ and CER were observed at the end of the daytime heating on both heating periods (Fig. 1; $240 \mathrm{~min}$ )., $g_{s}$ and consequently leaf transpiration decreased as a result of high temperatures 120 and $240 \mathrm{~min}$ after the shelters were closed for both pre- and post-silking (Fig. 1).

In contrast, internal $\mathrm{CO}_{2}$ concentration $\left(\mathrm{C}_{\mathrm{i}}\right)$ was not affected by heat stress (Fig. 1). Heating significantly increased average cell injury in $\mathrm{H} 1(+13.8$ and $+47.8 \%$ for $\mathrm{Tr}$ and $\mathrm{Tx}$, respectively) and $\mathrm{H} 2(+24.9$ and $+42.2 \%)$, when compared to the control treatments. Linear relationships between $F_{v} / F_{m}$ and $\mathrm{RCl}$ presented a significant negative association for both genotypes (Fig. 2: $R^{2}=0.84$ and $R^{2}=0.53$ for $T r$ and $T x$, respectively).

\section{Biomass production under heat stress and its association with physiological traits}

In addition, crop growth rate (CGR) declined when high temperatures were applied during pre- $(16.7 \%$ and $29.9 \%$ for $\mathrm{Tr}$ and $\mathrm{Tx}$, respectively; Fig. 3) and post-silking (22.4\% and $47.2 \%$, respectively). Strong associations were found between CGR and $\mathrm{RCl}, \mathrm{F}_{\mathrm{v}} / \mathrm{F}_{\mathrm{m}}$ and CER. For example, crop growth rate measured during post-silking $\left(\mathrm{CGR}_{\mathrm{POST}}\right)$ on $\mathrm{Tx}$ cultivar was strongly associated with $\mathrm{RCl}(r=-0.79 *$, measured on day 7 ; and $-0.92^{* * *}$, measured on day 14), $\mathrm{F}_{\mathrm{v}} / \mathrm{F}_{\mathrm{m}}\left(\mathrm{r}=0.88^{* *}\right.$ and $0.96^{* *}$, respectively) and CER ( $\mathrm{r}=$ $0.85^{*}$ and $0.93^{* *}$, respectively), when these variables were measured $120 \mathrm{~min}$ after the start of the daytime heating.

The principal component analysis (PCA, Fig. 4) allowed differentiating between temperature regimes and cultivars based on physiological traits and CGR. Thus, PC1 and PC2 explained $91 \%$ (pre-silking) and $87 \%$ (post-silking) of total variability. The PC1 of the biplots (Fig. 4) revealed that $F_{v} / F_{m}$, $g_{s}, \mathrm{E}, \mathrm{CER}$, and CGR were positively associated. All these vectors were positioned towards control plots. Conversely, $\mathrm{RCl}$ and LT were positioned in the opposite direction, towards the heat stress treatments (Fig. 4, A: pre-silking and B: post-silking), and no solid associations were inherent of the cultivar type. As a difference, $C_{i}$ was represented in PC2 and was not associated with any heat treatment or cultivar.

\section{Discussion}

Leaf temperature in heated plots reached nearly $40^{\circ} \mathrm{C}$, highlighting the heat treatments' effectiveness (i.e., $\mathrm{H} 1$ and $\mathrm{H} 2$; Table 1). Despite similar increases in average temperature (difference between control and heated plots), heating intensity was different between experiments; the number of hours plants in heated plots were exposed to temperatures exceeding $34^{\circ} \mathrm{C}$ nearly doubled during postsilking $(\mathrm{H} 2)$ when compared to pre-silking $(\mathrm{H} 1)$.

Our results revealed that CER was closely related to $F_{v} / F_{m}$ decreases during daytime heating and CER recovery seems strongly associated with the fast recoveries of $F_{v} / F_{m}$ after heat stress, in accordance with our first hypothesis. The temporary decline of $F_{v} / F_{m}$ in ear leaves, as well as the subsequent recovery from heat stress, indicate that damage to PSII was transient with exceptionally fast recoveries when 
Table 1. Effect of treatments on leaf temperature (LT: $\left.{ }^{\circ} \mathrm{C}\right)$, stomatal conductance $\left(g_{s}: \mathrm{mmol} \mathrm{H}_{2} \mathrm{O} \mathrm{m}^{-2} \mathrm{~s}^{-1}\right)$, leaf transpiration rate $(\mathrm{E}: \mathrm{mmol}$

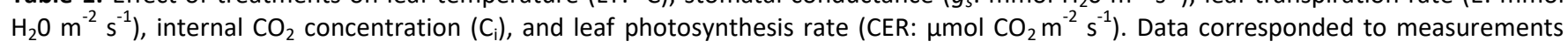
taken in the middle $(120 \mathrm{~min})$ and at the end $(240 \mathrm{~min})$ of the daytime heating in two maize cultivars (Tr: tropical and Tx: temperate $x$ tropical). Temperature regimes corresponded to control (C) and heated treatments $(H)$ during a 15-d period before silking (pre-silking) and heating from $R 1+2-d$ to $R 1+17-d$ (post-silking). ANOVA results are presented at the bottom of each heating period. All traits were measured in the middle $(7 \mathrm{~d})$ and at the end of the treatment period $(14 \mathrm{~d}) . \mathrm{LSD}_{0.05}$ is provided two-way interactions within each column.

\begin{tabular}{|c|c|c|c|c|c|c|c|c|c|c|c|c|}
\hline \multicolumn{13}{|c|}{ Pre-silking } \\
\hline \multirow[b]{2}{*}{ Day } & \multirow[b]{2}{*}{ TR } & \multirow[b]{2}{*}{ CUL } & \multicolumn{5}{|c|}{$\begin{array}{l}120 \text { minutes after the beginning of the daytime } \\
\text { heating }\end{array}$} & \multicolumn{5}{|c|}{$\begin{array}{l}240 \text { minutes after the beginning of the daytime } \\
\text { heating }\end{array}$} \\
\hline & & & LT‡ & $g_{s} \S$ & $\mathrm{E}$ & $C_{i} \cap$ & CER & LT & $g_{s}$ & $\mathrm{E}$ & $C_{i}$ & CER \\
\hline \multirow[t]{4}{*}{7} & $\mathrm{C} 1$ & $\mathrm{Tr}$ & 33.1 & 0.438 & 7.75 & 129.5 & 36.1 & 34.4 & 0.415 & 6.54 & 109.7 & 38.0 \\
\hline & & $T x$ & 32.9 & 0.460 & 7.80 & 151.1 & 36.3 & 34.6 & 0.440 & 6.60 & 107.8 & 37.7 \\
\hline & $\mathrm{H} 1$ & $\mathrm{Tr}$ & 38.5 & 0.252 & 6.03 & 130.4 & 31.3 & 40.0 & 0.203 & 4.49 & 105.4 & 24.6 \\
\hline & & $T x$ & 38.6 & 0.255 & 6.00 & 144.6 & 25.3 & 40.5 & 0.181 & 4.63 & 108.5 & 20.8 \\
\hline TR & & & $* * *$ & $* * *$ & $* * *$ & nst $^{+}$ & $* *$ & $* * *$ & $* * *$ & $* * *$ & $* * *$ & $* * *$ \\
\hline CUL & & & ns & ns & ns & ns & ns & ns & ns & ns & ns & ns \\
\hline \multirow[t]{2}{*}{ TR*CUL } & & & ns & ns & ns & ns & $*$ & ns & ns & ns & ns & $*$ \\
\hline & & $\begin{array}{l}\text { LSD } \\
\text { (interacti } \\
\text { on) }\end{array}$ & 1.1 & 0.051 & 0.34 & 26.4 & 4.4 & 1.2 & 0.030 & 0.78 & 40.3 & 3.8 \\
\hline Day & $\mathrm{TR}$ & CUL & LT & $g_{s}$ & $E$ & $C_{i}$ & CER & LT & $g_{s}$ & $E$ & $C_{i}$ & CER \\
\hline \multirow[t]{4}{*}{14} & C1 & $\mathrm{Tr}$ & 32.5 & 0.373 & 6.37 & 131.7 & 35.0 & 31.8 & 0.340 & 6.02 & 125.3 & 32.9 \\
\hline & & Tx & 31.5 & 0.403 & 6.53 & 158.0 & 34.2 & 32.5 & 0.333 & 5.80 & 110.0 & 32.2 \\
\hline & $\mathrm{H} 1$ & $\operatorname{Tr}$ & 40.9 & 0.239 & 5.25 & 145.0 & 28.4 & 41.7 & 0.245 & 4.82 & 101.7 & 25.3 \\
\hline & & $T x$ & 41.7 & 0.220 & 5.00 & 125.0 & 25.9 & 42.1 & 0.233 & 4.61 & 130.7 & 23.5 \\
\hline \multicolumn{3}{|l|}{ TR } & $* * *$ & $* * *$ & $* * *$ & ns & $* * *$ & $* * *$ & $* * *$ & $* * *$ & ns & $* * *$ \\
\hline \multicolumn{3}{|l|}{ CUL } & ns & ns & ns & ns & ns & ns & ns & ns & ns & ns \\
\hline \multicolumn{3}{|c|}{ TR*CUL } & ns & ns & ns & ns & ns & ns & ns & ns & ns & $*$ \\
\hline \multicolumn{3}{|c|}{ LSD (interaction) } & 2.4 & 0.059 & 0.78 & 35.9 & 4.4 & 1.7 & 0.028 & 0.53 & 35.5 & 2.3 \\
\hline
\end{tabular}

\begin{tabular}{|c|c|c|c|c|c|c|c|c|c|c|c|c|}
\hline \multicolumn{13}{|c|}{ Post-silking } \\
\hline \multirow[b]{2}{*}{ Day } & \multirow[b]{2}{*}{ TR } & \multirow[b]{2}{*}{ CUL } & \multicolumn{5}{|c|}{$\begin{array}{l}120 \text { minutes after the beginning of the daytime } \\
\text { heating }\end{array}$} & \multicolumn{5}{|c|}{$\begin{array}{l}240 \text { minutes after the beginning of the daytime } \\
\text { heating }\end{array}$} \\
\hline & & & LT & $g_{s}$ & $E$ & $\mathrm{C}_{\mathrm{i}}$ & CER & LT & $g_{s}$ & $E$ & $C_{i}$ & CER \\
\hline \multirow[t]{4}{*}{7} & $\mathrm{C} 2$ & $\mathrm{Tr}$ & 32.4 & 0.387 & 6.49 & 116.7 & 34.8 & 34.6 & 0.313 & 5.93 & 118.3 & 32.9 \\
\hline & & $T x$ & 32.8 & 0.378 & 6.00 & 153.7 & 34.0 & 34.2 & 0.314 & 5.80 & 116.7 & 32.1 \\
\hline & $\mathrm{H} 2$ & $\operatorname{Tr}$ & 41.6 & 0.305 & 4.80 & 146.3 & 29.6 & 44.8 & 0.223 & 3.83 & 112.7 & 25.5 \\
\hline & & $\mathrm{Tx}$ & 41.3 & 0.299 & 4.37 & 137.3 & 28.4 & 44.8 & 0.215 & 3.90 & 126.3 & 20.9 \\
\hline \multicolumn{3}{|l|}{ TR } & $* * *$ & $* * *$ & $* *$ & ns & $* *$ & $* *$ & $* * *$ & $* *$ & ns & $* * *$ \\
\hline \multicolumn{3}{|l|}{ CUL } & ns & ns & ns & ns & ns & ns & ns & ns & ns & $*$ \\
\hline \multicolumn{3}{|c|}{ TR*CUL } & ns & ns & ns & ns & ns & ns & ns & ns & ns & ns \\
\hline \multicolumn{3}{|c|}{ LSD (interaction) } & 2.5 & 0.028 & 1.09 & 37.6 & 2.3 & 2.0 & 0.031 & 1.56 & 45.3 & 3.8 \\
\hline Day & TR & CUL & LT & $g_{s}$ & $E$ & $\mathrm{C}_{\mathrm{i}}$ & CER & LT & $g_{s}$ & $E$ & $\mathrm{C}_{\mathrm{i}}$ & CER \\
\hline \multirow[t]{4}{*}{14} & $\mathrm{C} 2$ & $\mathrm{Tr}$ & 32.1 & 0.395 & 6.48 & 151.7 & 34.8 & 34.9 & 0.324 & 5.82 & 124.0 & 32.9 \\
\hline & & $T x$ & 32.0 & 0.402 & 6.48 & 133.3 & 31.9 & 34.7 & 0.312 & 5.57 & 112.3 & 29.8 \\
\hline & $\mathrm{H} 2$ & $\mathrm{Tr}$ & 38.1 & 0.303 & 5.10 & 133.0 & 27.3 & 43.5 & 0.234 & 4.13 & 127.3 & 24.5 \\
\hline & & $T x$ & 38.9 & 0.294 & 4.95 & 159.0 & 26.5 & 43.7 & 0.237 & 4.19 & 123.7 & 21.7 \\
\hline \multicolumn{3}{|l|}{ TR } & $* * *$ & $* * *$ & $* * *$ & ns & $* * *$ & $* * *$ & $* * *$ & $* * *$ & ns & $* * *$ \\
\hline \multicolumn{3}{|l|}{ CUL } & ns & ns & ns & ns & $*$ & ns & ns & ns & ns & $* * *$ \\
\hline \multicolumn{3}{|c|}{$\mathrm{TR}^{*} \mathrm{CUL}$} & ns & ns & ns & ns & ns & ns & ns & ns & ns & ns \\
\hline \multicolumn{3}{|c|}{ LSD (interaction) } & 1.4 & 0.030 & 0.80 & 33.2 & 2.31 & 0.93 & 0.019 & 0.71 & 33.2 & 3.6 \\
\hline
\end{tabular}


Pre-silking
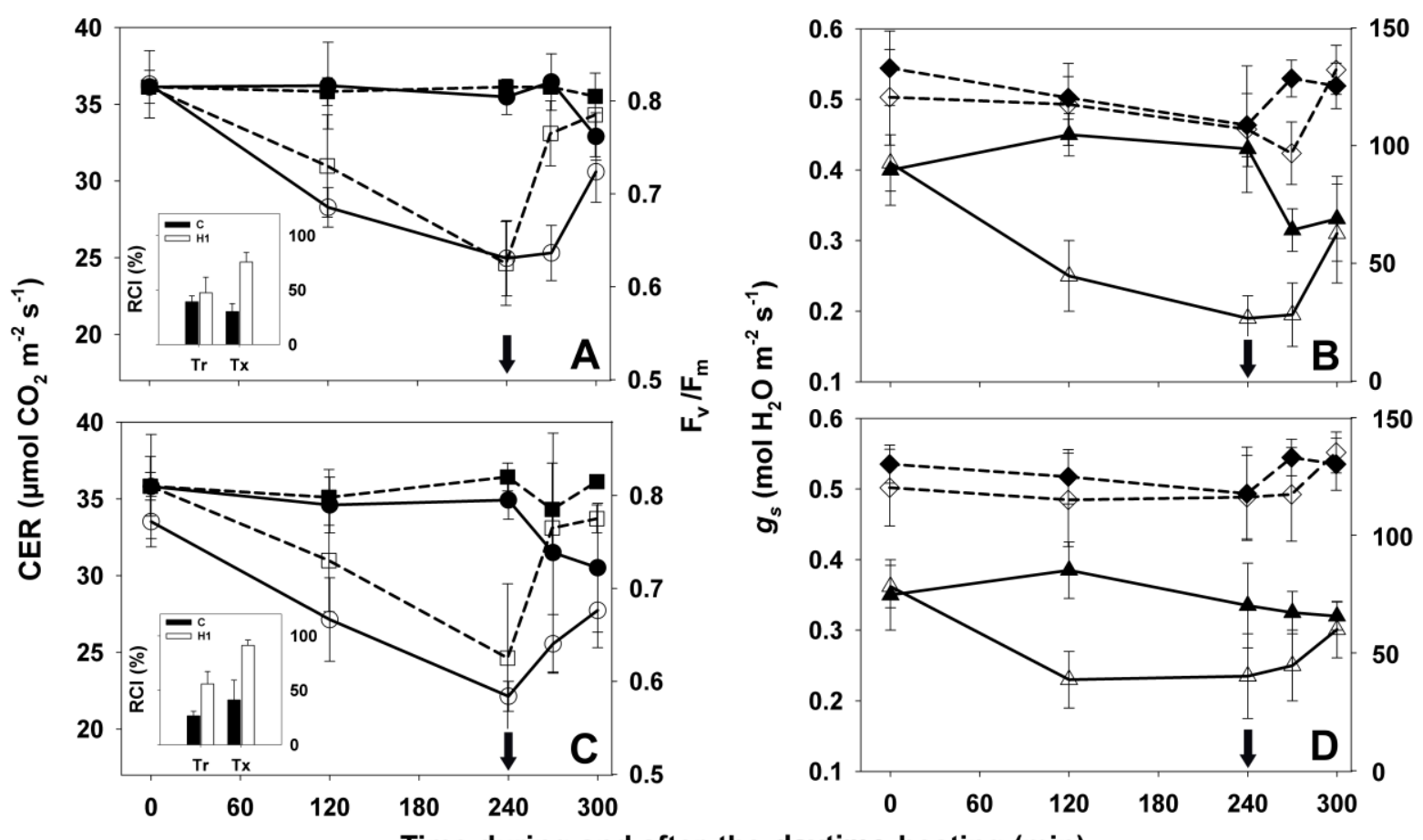

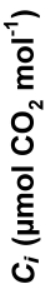

Time during and after the daytime heating (min)

Post-silking
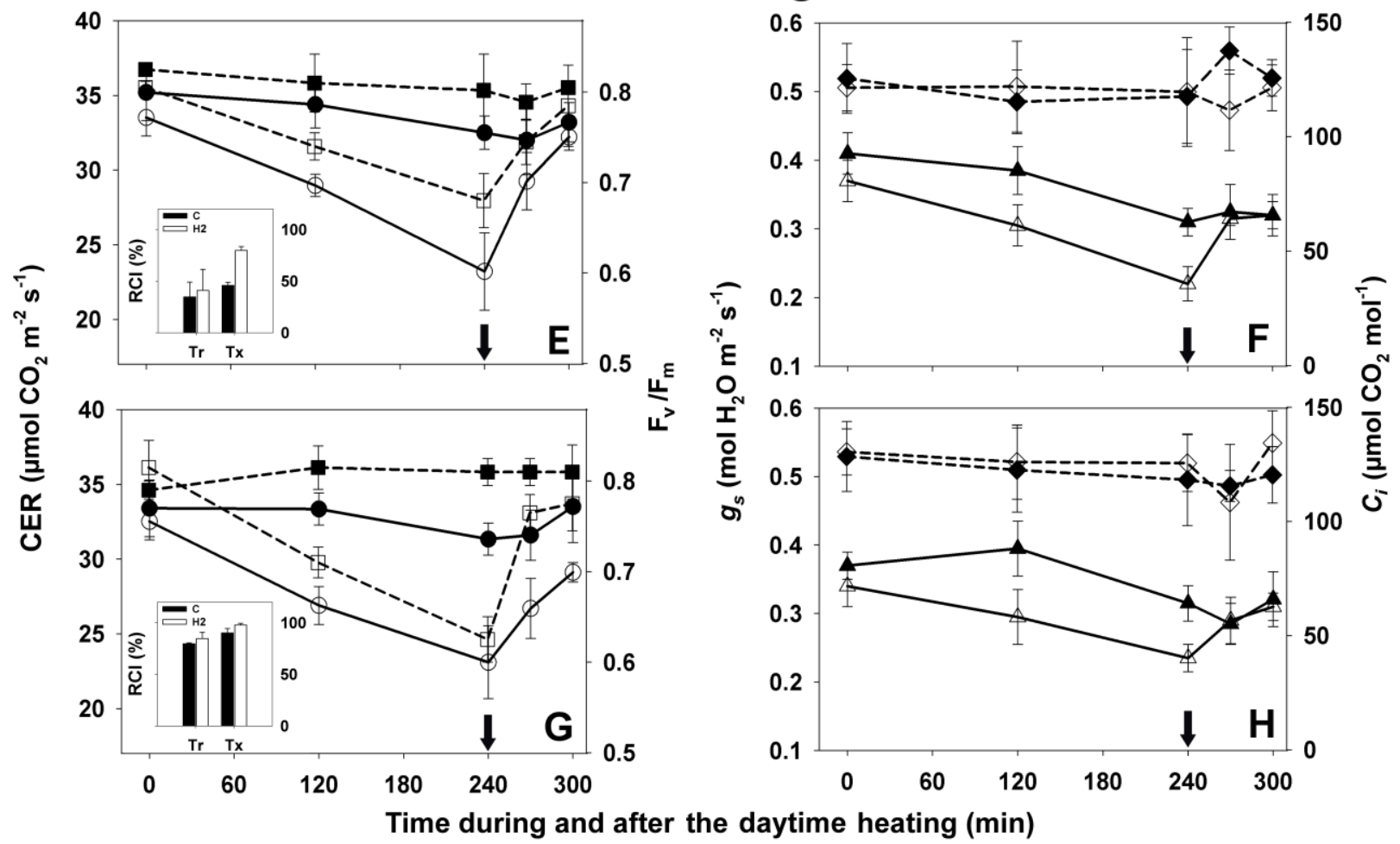

Fig 1. Leaf photosynthesis rate (CER, circles), maximum efficiency of PSII ( $F_{v} / F_{m}$, squares), stomatal conductance $\left(g_{s}\right.$, triangles) and internal $\mathrm{CO}_{2}$ concentration ( $\mathrm{C}_{\mathrm{i}}$, diamonds) as a function of time during and after the daytime heating. Data corresponds to the average of two maize cultivars under control (closed symbols) and heat conditions (open symbols). Arrows indicate the time when shelters were reopened at the end of the daytime heating treatment. Measurements were taken on day $7(A, B, E$ and $F)$ and day 14 (C, D, G and H) after the start of the heating period in pre- and post-silking. Relative cell injury (RCl) was also measured (inset) $120 \mathrm{~min}$ after initiating the daytime heating in both cultivars (Tr: tropical and Tx: tropical $\times$ temperate). Leaf photosynthesis data (CER) were partially obtained from Neiff et al., 2016. 

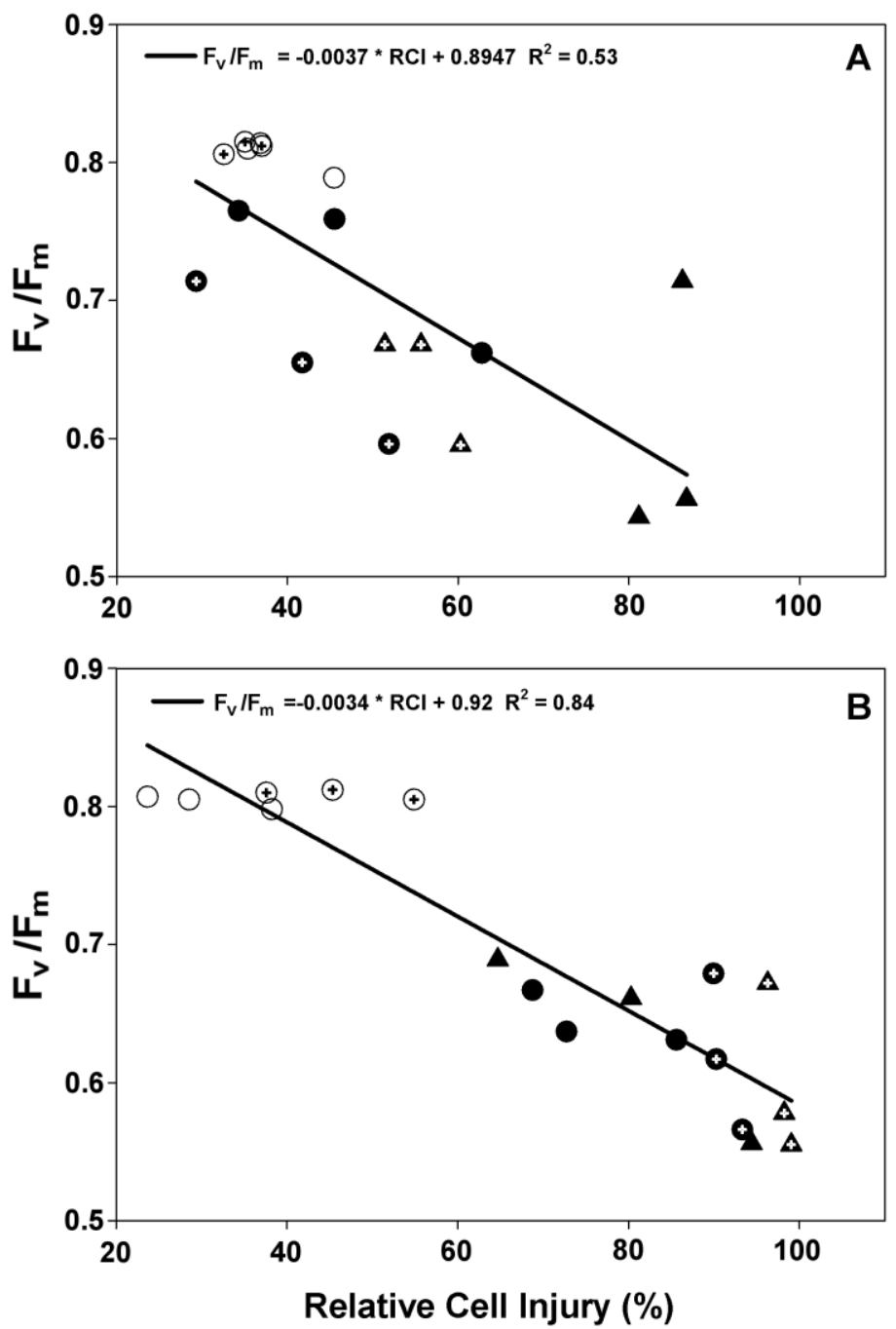

Fig 2. Relationship between maximum efficiency of PSII $\left(F_{v} / F_{m}\right)$ and relative cell injury. Data corresponds to two maize genotypes, (A; Tropical and B; Tropical $\times$ Temperate) under control (open symbols) and heating conditions (closed symbols). Treatments were performed during a 15-d period before silking (circles) and from R1 + 2-d to R1 + 17-d (triangles). Symbols with or without a plus sign represent measurements taken on day 7 or day 14 , respectively. Data corresponded to measurements taken 120 min after the start of the daytime heating.

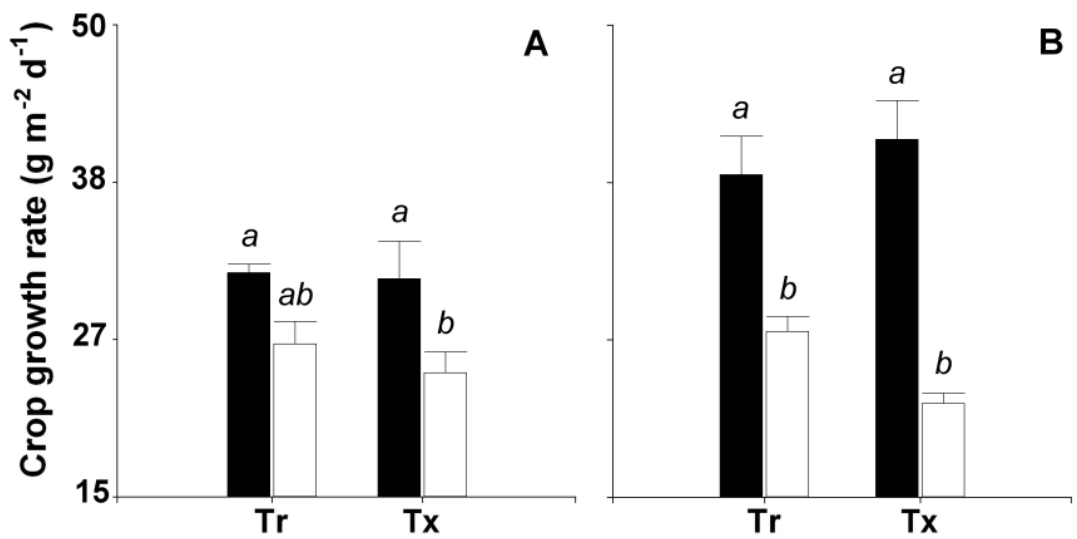

Fig 3. Crop growth rate $\left(\mathrm{g} \mathrm{m}^{-2} \mathrm{~d}^{-1}\right.$ ) at pre- (A) and post-silking (B). Data corresponded to two maize cultivars (Tr: tropical and Tx: tropical $\times$ temperate) under control (shaded bars) or heated conditions (blank bars). Vertical bars denote \pm S.E. of means. Bars with same letters are not significantly different $(P<0.05)$. 

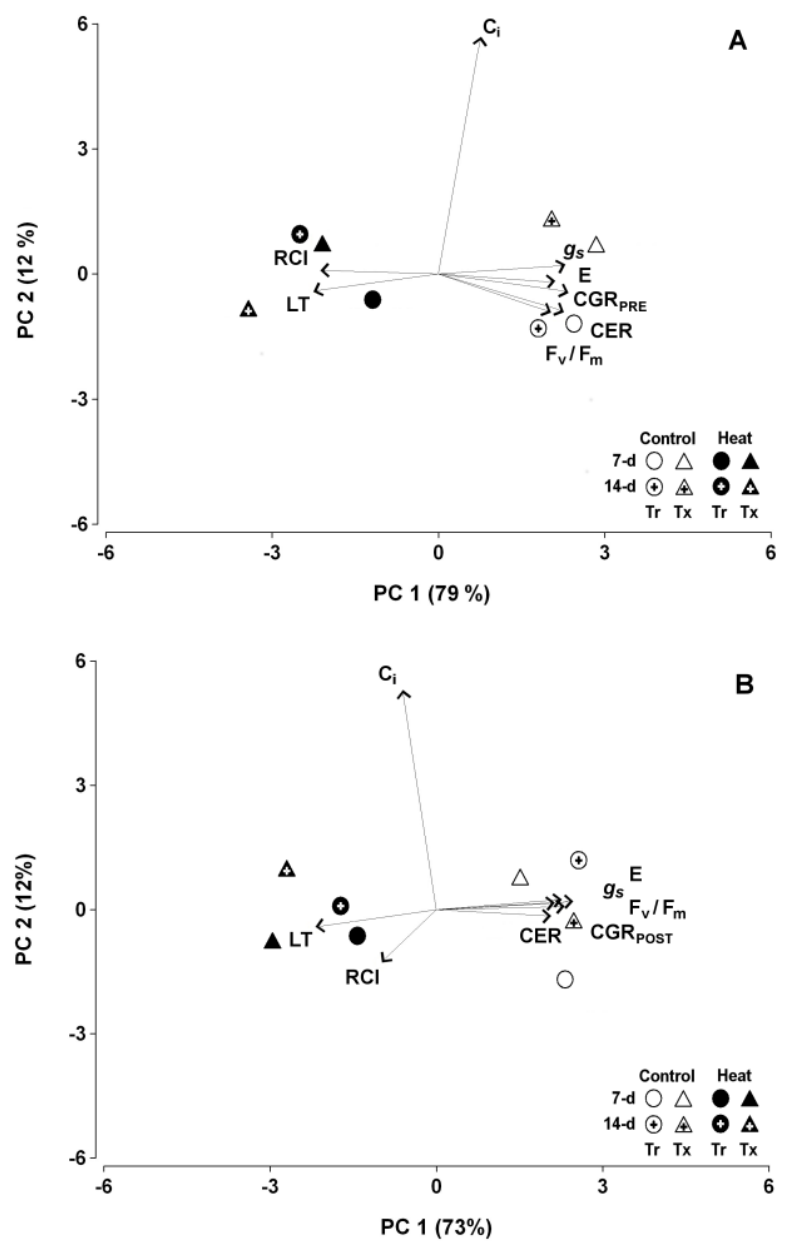

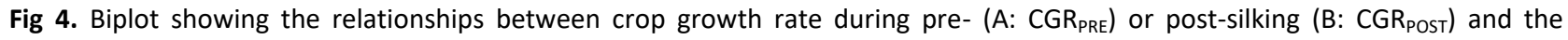
physiological traits measured in each period: relative cell injury $(\mathrm{RCI})$, maximum efficiency of $P S I I\left(F_{v} / F_{m}\right)$, stomatal conductance $\left(g_{s}\right)$, leaf transpiration $(E)$, leaf temperature $(\mathrm{LT})$, internal $\mathrm{CO}_{2}$ concentration $\left(\mathrm{C}_{\mathrm{i}}\right)$, and leaf photosynthesis rate (CER). Data corresponded to the average of two maize cultivars, ( $\mathrm{Tr}$ ) Tropical and (Tx) Tropical x Temperate; under control (blank symbols) and heat (shaded symbols) stress conditions. Measurements were taken in the middle (7-d; symbols without a plus sign) and at the end (14-d; symbols with a plus sign) of each heating period.

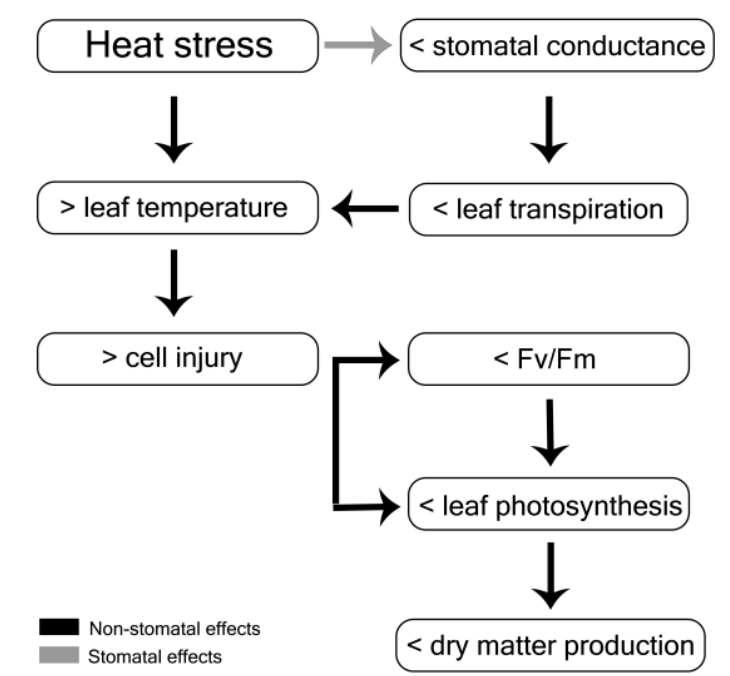

Fig 5. Chart showing possible non-stomatal and stomatal effects of heat stress under field conditions in maize. 
compared to other studies. $F_{v} / F_{m}$ of heated leaves reached $\sim 95 \%$ of the corresponding control values $30 \mathrm{~min}$ after the end of the daytime heating (Fig. 1). This is one of the most remarkable findings of the current research. Similarly, Haldimann and Feller (2005) reported relative fast recoveries of $F_{v} / F_{m}$ in pea (Pisum sativum L.) leaves acclimated to heat stress. Conversely, in maize, several studies indicated that $\mathrm{F}_{\mathrm{v}} / \mathrm{F}_{\mathrm{m}}$ in dark-adapted leaves and leaf photosynthesis recoveries occurred within a window of time from hours to even days (Heckathorn et al., 1998, Sinsawat et al., 2004, Souza et al., 2004).

The results also clearly reveal that the photosynthesis reduction during heat stress under field conditions was mainly determined by non-stomatal factors, in agreement with our second hypothesis. Although stomatal conductance was affected by the temperature regimes, this did not seem to be the direct cause of photosynthesis reduction, because it was not directly related to changes in $\mathrm{CO}_{2}$ concentration in the stomatal cavity $\left(C_{i}\right.$, Fig. 4). Hence, stomatal closure appeared to be a secondary response to heat stress, according to earlier studies (Berry and Bjorkman, 1980, Heckathorn et al., 1998). Similarly, Camejo et al. (2005) concluded that heat shock treatment in tomato caused important reductions in CER associated with non-stomatal components. In contrast, Zhou et al. (2007) found that photosynthesis decreases by drought stress in rice were due to both diffusive (stomatal conductance) and metabolic (oxidative damage to the chloroplast) limitations, depending on the intensity of the drought stress. In this research, both temperature regimes (TR) and the cultivar $x$ treatment interaction did not have a significant effect on $C_{i}$ during heating (Table 1 and Fig. 1). Similarly, Sharma et al. (2015) also found that $C_{i}$ was unaffected by heat stress in wheat (Triticum aestivum).

Relative cell injury $(\mathrm{RCl})$ was acceptably $\left(\mathrm{Tr}\right.$, Fig. $2 \mathrm{~A}: \mathrm{R}^{2}=$ $0.53^{*}$ ) or strongly (Tx, Fig. $2 \mathrm{~B}: \mathrm{R}^{2}=0.84^{* *}$ ) associated with $F_{v} / F_{m}$. As a consequence of the artificial heating, cell injury increased from $-7 \mathrm{~d}$ before silking to $+14 \mathrm{~d}$ post-silking. Furthermore, cell membranes in ear leaves of Tx were highly susceptible to heat stress in comparison with $\mathrm{Tr}$, and consequently less stable as temperature increased, resulting in a massive leakage of ions from the damaged cells. These findings support the use of cell membrane stability to discriminate heat-tolerant and susceptible cultivars (Coskun et al., 2011, Rahman et al., 2004).

Crop growth rate (CGR) was reduced by heat stress in both heating periods. These results are supported by previous findings based on maize cultivars, where authors reported greater effects of heating on radiation efficiency use than on light interception (Cicchino et al., 2010; Rattalino Edreira and Otegui, 2012). In addition, we found that CGR was positively associated with CER and $F_{v} / F_{m}$ across heating periods and cultivars, and negatively associated with $\mathrm{RCl}$, in agreement with our third hypothesis. Apparently, CER and $F_{v} / F_{m}$ recoveries observed in our study could be translated to crop level, as indicated by previous studies (Rattalino Edreira and Otegui, 2012). The authors showed that after the removal of heat stress, plants subjected to heat stress around silking exhibited a recovery in growth and reached crop growth rate values similar to those registered among non-heated plants. In addition, Neiff et al. (2016) found an important recovery

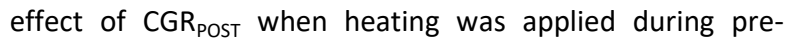
silking. Sharma et al. (2015), also found that dry matter accumulation in wheat after 7 days of heat stress was positively correlated to $F_{v} / F_{m}$, and this trait was used to compare the ability of chlorophyll fluorescence parameters to detect genetic differences in heat tolerance (Sharma et al., 2012). Furthermore, heat treatments were clustered with high relative cell injury and high leaf temperatures, and physiological traits were reduced significantly under heat stress conditions each day measurements were taken (Fig. 4).

Finally, non-stomatal limitation seems to be the main cause of CER and crop growth rate decreases in maize when heat stress was applied close to silking under field conditions, since $C_{i}$ was not affected by heating. Stomatal closure could have indirectly contributed to an increase in cell injury through a decrease of transpiration rate, and hence, an increase in leaf temperature. Cell injury could affect photosynthesis by directly affecting PSII potential activity (quantified as $F_{v} / F_{m}$ ) or by other metabolic ways, such as rubisco activity, reactive oxygen species, etc. The consequence of what was described above is, clearly, a reduction of dry matter production. A fairly generalized scheme is given in Fig. 5, which shows the relationships among some of the measured traits under high temperature.

Further research is needed in order to analyze the impact of heat on the other metabolic traits mentioned above. The observed correlations between physiological traits and crop growth rate during heat stress under field conditions are indicative of the potential use of these traits in breeding programs for heat tolerance.

\section{Materials and Methods}

\section{Plant material and growing conditions}

Field experiments were conducted at the Universidad Nacional del Nordeste experimental station (Corrientes, Argentina; $27^{\circ} 28^{\prime} \mathrm{S} ; 58^{\circ} 49^{\prime} \mathrm{W} ; 70$ masl). The area has a humid subtropical climate. Two single cross maize cultivars (Tr: tropical and Tx: temperate $x$ tropical; cultivar: CUL) with contrasting temperature tolerance (Neiff et al., 2016) were planted on January $18^{\text {th }}(\mathrm{Tr})$ and $20^{\text {th }}(\mathrm{Tx}), 2014$. The sowing dates were used to synchronize silking dates between cultivars based on previous experiments (data not shown). Two seeds were sown per hill, and then thinned to one plant per hill at V3 stage, resulting in a final plant density of 7.5 plants $\mathrm{m}^{-2}$ ( $0.5 \mathrm{~m}$ row to row spacing). The cultivars were DK 390 VT3Pro (Tr) and Exp 8282 VT3Pro (Tx), both produced by Monsanto Argentina. The soil was a Hyperthermic Aquic Udipsament. Soil water was kept over $50 \%$ field capacity in the first meter of depth during the entire growing season using drip irrigation. Plots were fertilized with $250 \mathrm{~kg} \mathrm{~N} \mathrm{ha}^{-1}$, $60 \mathrm{~kg} \mathrm{P} \mathrm{ha}^{-1}$, and $199 \mathrm{~kg} \mathrm{~K} \mathrm{ha}^{-1}$ via drip irrigation system. Weeds, insects, and diseases were controlled as needed.

\section{Experimental design}

The experiments were established in a split-plot design with three replications. The main plots $\left(30 \mathrm{~m}^{-2}\right)$ were enclosed in polyethylene film shelters $(5 \mathrm{~m}$ long, $7.5 \mathrm{~m}$ wide with a maximum height of $3 \mathrm{~m}$ ), which were used to control temperature increases. High temperature was induced by shelter closure through roll-up shutters arranged on both 
sides of each shelter during the pre- (15-day period before silking to R1) and post-silking periods (15-day period beginning two days after silking). Thus, two temperature regimes were applied during the pre- ( $\mathrm{C} 1$ : control and $\mathrm{H} 1$ : heated) and post-silking periods ( $\mathrm{C} 2$ and $\mathrm{H} 2$ ). During heating in $\mathrm{H} 1$ and $\mathrm{H} 2$, the roll-up shutter was not fully closed leaving an opening of $0.5 \mathrm{~m}$ above ground at the sides of shelters in order to allow adequate gas exchange and avoid excessive heating. Temperature increases in $\mathrm{H} 1$ (pre-silking) and $\mathrm{H} 2$ (post-silking) treatments varied from $4^{\circ}$ to $10^{\circ} \mathrm{C}$ from 1000 to $1400 \mathrm{~h}$ during the treatment period $(15 \mathrm{~d})$. Temperatures were left at ambient levels in control treatments (C1 and C2) in which the roll-up shutter remained fully open. Temperature regimes were randomly assigned to main plots, whereas cultivars were randomly assigned to sub-plots (10 $\mathrm{m}^{-2}$ ) within the main plots.

\section{Leaf gas exchange and chlorophyll fluorescence}

Steady-state leaf photosynthesis (CER, $\mu \mathrm{mol} \mathrm{CO}_{2} \mathrm{~m}^{-2} \mathrm{~s}^{-1}$ ) was measured with a LI-COR 6400 portable photosynthesis system (LI-COR, Lincoln, NE) under saturated irradiances.

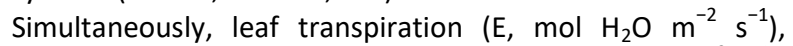
stomatal conductance to water vapor $\left(g_{s}, \mathrm{~mol} \mathrm{H}_{2} \mathrm{O} \mathrm{m}^{-2} \mathrm{~s}^{-1}\right)$, and internal $\mathrm{CO}_{2}$ concentration $\left(\mathrm{C}_{\mathrm{i}}, \mu \mathrm{mol} \mathrm{mol}{ }^{-1}\right)$ were also determined. All measurements were taken from fully expanded ear leaves. CER at leaf surface measured 2000 $\mu \mathrm{mol} \mathrm{m} \mathrm{m}^{-2} \mathrm{~s}^{-1}$ PPFD (i.e., photosynthetic photon flux density) using a 6400-40 leaf chamber on a $2 \mathrm{~cm}^{-2}$ area of the leaf that did not include the midrib. Flow rate through the chamber and sample side IRGA was set to $500 \mu \mathrm{mol} \mathrm{s}^{-1} . \mathrm{CO}_{2}$ concentration of the reference cell $\left(\mathrm{CO}_{2} \mathrm{R}\right)$ was set at 400 $\mathrm{ppm}$. In order to assess the daily evolution of CER, E, $g_{s}$ and $C_{i}$, measurements were performed 0,120 , and 240 minutes after initiating the daytime heating and every 30 minutes after the removal of heat stress on days 7 and 14 during the heating period (measurement day: Md). Measurements of maximum efficiency of PSII $\left(F_{v} / F_{m}\right)$ were taken simultaneously with CER. The ear leaves were dark-adapted for $30 \mathrm{~min}$ before using a Handy-PEA chlorophyll fluorometer (Hansatech, UK). The transients were induced by $1 \mathrm{~s}$ illumination with an array of six light-emitting diodes providing maximum light intensity $\left(3500 \mu \mathrm{mol} \mathrm{m}^{-2} \mathrm{~s}^{-1}\right.$ PPFD) and homogeneous irradiation over a leaf area of $0.13 \mathrm{~cm}^{-2}$. $\mathrm{F}_{\mathrm{v}} / \mathrm{F}_{\mathrm{m}}$ measurements were also performed in the middle and at the end of each heating period (i.e., days 7 and 14).

\section{Cell membrane stability (CMS)}

Relative cell injury $(\mathrm{RCl})$ was calculated with the following equation:

$R C I(\%)=100-C M S[1]$

CMS: cell membrane stability

CMS was measured with the method suggested by Sullivan (1972) and adapted by Rhaman et al. (2004). The combination of temperature and duration treatments exposing maximum genotypic differences $\left(40^{\circ} \mathrm{C}\right.$ for $\left.60 \mathrm{~min}\right)$ was selected for these experiments. Measurements were taken on days 7 and 14 of each heating period (i.e., pre- and post-silking). Ear leaf samples were taken from maize plants to determine relative injury at noon (120 min after initiating the daytime heating). Leaves were brought to the laboratory as quickly as possible. A special steel puncher was used for punching leaf discs $\left(0.95 \mathrm{~cm}^{-2}\right)$. Two samples were taken from each ear leaf (one on either side of the rib). Leaf discs were excised between 1200 and $1300 \mathrm{~h}$ and placed in tubes. Leaf discs were thoroughly rinsed thrice in deionized water to wash out any adherent electrolytes. After the final washing, $2 \mathrm{~mL}$ water were added to each tube and capped to avoid desiccation and evaporation during heating. One sample was treated in a controlled temperature water bath maintained at $40^{\circ} \mathrm{C}$ for 60 minutes. The other sample was kept at $25^{\circ} \mathrm{C}$ for the same period. After heating, $10 \mathrm{~mL}$ deionized water were added to each vial and held at $10^{\circ} \mathrm{C}$ for $24 \mathrm{~h}$ to allow for diffusion of electrolytes. Vials were brought to $25^{\circ} \mathrm{C}$ and shaken to mix the contents. Electrical conductivity $(\mathrm{EC})$ was measured with an EC-meter (Model, HI-933300, Hanna Instruments, USA). Vials were autoclaved for 15 minutes at $0.10 \mathrm{MPa}$ pressure to completely kill tissues and release all electrolytes. Vials were then brought to $25^{\circ} \mathrm{C}$ and the final EC was measured with the same tool. CMS was calculated with the following equation (Sullivan, 1972):

CMS $(\%)=\left[\frac{1-\left(\frac{T 1}{T_{2}}\right)}{1-\left(\frac{C 1}{C 2}\right)}\right] \times 100[2]$

$T$ and $C$ refer to EC values of heat-treated and controlled vials, and subscripts 1 and 2 denote the initial and final EC readings, respectively.

\section{Crop growth rate}

Crop growth rate data (CGR, $\mathrm{g} \mathrm{m}^{-2} \mathrm{~d}^{-1}$ ) was obtained from Neiff et al., 2016. Briefly, authors measured dry matter destructively by harvesting five consecutive plants at presilking (-15 d R1), silking (R1) and $15 \mathrm{~d}$ after silking. The calculation was performed as the quotient of the difference of shoot dry matter produced and the time elapsed between samplings. Crop growth rate was estimated for the pre$\left(\mathrm{CGR}_{\mathrm{PRE}}\right)$ and post-silking ( $\left.\mathrm{CGR}_{\mathrm{POST}}\right)$ periods.

\section{Statistical analysis}

Data were compared using ANOVA, Pearson's correlations among traits and simple linear regression analysis for pairwise comparisons. Differences among treatment means were separated by the least significant difference (LSD) Fisher's test at 0.05 probability level. A principal component analysis (PCA) was used to identify physiological variables associated with dry matter production in both heating periods (i.e., pre- and post-silking). All tests were performed with Infostat 2011 software.

\section{Conclusion}

Our results indicate that, for maize plants growing under high temperatures, relative cell injury $(\mathrm{RCl})$ and $\mathrm{F}_{\mathrm{v}} / \mathrm{F}_{\mathrm{m}}$ were strongly associated with decreases in CER, and that $F_{v} / F_{m}$ recoveries were exceptionally faster in comparison with other studies. These findings reaffirm the close relationship between $F_{v} / F_{m}$ and leaf photosynthesis recoveries. In this sense, measurement of post-stress recovery could be a relevant trait in order to aid breeding for heat-tolerant germplasm. Moreover, internal $\mathrm{CO}_{2}$ concentrations were similar among temperature regimes, discarding a causal primary effect of stomatal conductance and highlighting the damage on non-stomatal factors such as PSII activity under 
heat stress.

\section{Acknowledgments}

The authors wish to thank G. Zacarias, N. May Petroff, Y. Namtz, J. Morello, and E. Casañas for technical assistance. This research was financed by the INTA through Foundation ArgenINTA and PNCYO-1127042, Monsanto Argentina, and CONICET. N. Neiff has a postdoctoral scholarship from CONICET. F.H. Andrade is a member of CONICET.

\section{References}

Ainsworth EA, Ort DR (2010) How do we improve crop production in a warming world? Plant Physiol. 154:526530

Berry J, Bjorkman O (1980) Photosynthetic response and adaptation to temperature in higher plants. Annu Rev Physiol. 31:491-543.

Bunce JA (2005) What is the usual internal carbon dioxide concentration in $\mathrm{C} 4$ species under midday field conditions? Photosynthetica. 43:603-608.

Camejo D, Rodríguez P, Angeles Morales M, Miguel Dell'Amico J, Torrecillas A, Alarcón JJ (2005) High temperature effects on photosynthetic activity of two tomato cultivars with different heat susceptibility. J Plant Physiol. 162:281-289.

Cicchino M, Rattalino Edreira JI, Uribelarrea M, Otegui ME (2010) Heat Stress in field-grown maize: response of physiological determinants of grain yield. Crop Sci. 50:1438-1448.

Coskun Y, Coskun A, Demirel U, Özden M (2011) Physiological response of maize (Zea mays L.) to high temperature stress. Aust J Crop Sci. 5:966-972.

Ergo VV, Lascano R, Vega CR, Parola R, Carrera CS (2018) Heat and water stressed field- grown soybean: $A$ multivariate study on the relationship between physiological-biochemical traits and yield. Environ Exp Bot. 148:1-11.

Fischer G, Shah M, Tubiello FN, Velhuizen H (2005) Socioeconomic and climate change impacts on agriculture: an integrated assessment, 1990-2080. Philos T Roy Soc B. 360:2067-2083.

Haldimann P, Feller U (2005) Growth at moderately elevated temperature alters the physiological response of the photosynthetic apparatus to heat stress in pea (Pisum sativum L.) leaves. Plant Cell Environ. 28:302-317.

Havaux M, Greppin H, Strasser RJ (1991) Functioning of Photosystems I and II in pea leaves exposed to heat stress in the presence or absence of light. Planta. 186:88-98.

Havaux M, Tardy F (1996) Temperature-dependent adjustment of the thermal stability of photosystem II in vivo: possible involvement of xanthophyll-cycle pigments. Planta. 198:324-333.

Havaux M, Tardy F, Ravenel J, Chanu D, Parot P (1996) Thylakoid membrane stability to heat stress studied by flash spectroscopic measurements of the electrochromic shift in intact potato leaves: influence of the xanthophyll content. Plant Cell Environ. 19:1359-1368.

Heckathorn SA, Coleman JS, Hallberg RL (1998) Recovery of net $\mathrm{CO}_{2}$ assimilation after heat stress is correlated with recovery of oxygen-evolving-complex proteins in Zea mays L. Photosynthetica. 34:13-20.
Howarth CJ (1991) Molecular responses of plants to an increased incidence of heat shock. Plant Cell Environ. 14:831-841.

Karim MA, Fracheboud Y, Stamp P (1999) Photosynthetic activity of developing leaves of Zea mays is less affected by heat stress than that of developed leaves. Physiol Plantarum. 105:685-693.

Neiff N, Trachsel S, Valentinuz OR, Balbi CN, Andrade FH (2016) High temperatures around flowering in maize: Effects on photosynthesis and grain yield in three genotypes. Crop Sci. 56:2702-2712.

Quinn PJ, Williams WP (1985) Environmentally induced changes in chloroplast membranes and their effects on photosynthetic function. Photosynthetic Mechanisms and the Environment. 6:1-47.

Rahman H, Malik SA, Saleem M (2004) Heat tolerance of upland cotton during the fruiting stage evaluated using cellular membrane thermostability. Field Crops Res. 85:149-158.

Rattalino Edreira JI, Otegui ME (2012) Heat stress in temperate and tropical maize hybrids: Differences in crop growth, biomass partitioning and reserves use. Field Crops Res. 130:87-98.

Saadalla MM, Quick JS, Shanahan JF (1990) Heat tolerance in winter wheat: II. membrane thermostability and field performance. Crop Sci. 30:1248-1251.

Schmidhuber J, Tubiello FN (2007) Global food security under climate change. P Natl Acad Sci USA. 104:1970319708.

Shanahan JF, Edwards IB, Quick JS, Fenwick JR (1990) Membrane thermostability and heat tolerance of spring wheat. Crop Sci. 30:247-251.

Sharma, DK, Andersen, SB, Ottosen, CO, Rosenqvist, E (2012) Phenotyping of wheat cultivars for heat tolerance using chlorophyll a fluorescence. Funct Plant Biol. 39:936-947.

Sharma DK, Andersen SB, Ottosen CO, Rosenqvist E (2015) Wheat cultivars selected for high $F_{v} / F_{m}$ under heat stress maintain high photosynthesis, total chlorophyll, stomatal conductance, transpiration and dry matter. Physiol Plantarum. 153:284-298.

Sinsawat V, Leipner J, Stamp P, Fracheboud Y (2004) Effect of heat stress on the photosynthetic apparatus in maize (Zea mays L.) grown at control or high temperature. Environ Exp Bot. 52:123-129.

Souza RP, Machado EC, Silva JA, Lagôa AM, Silveira JA (2004) Photosynthetic gas exchange, chlorophyll fluorescence and some associated metabolic changes in cowpea (Vigna unguiculata) during water stress and recovery. Environ Exp Bot. 51:45-56.

Sullivan, CY (1972) Mechanisms of heat and drought resistance in grain sorghum and methods of measurement. In: Rao NGP (ed.): Sorghum in Seventies, 247-264 (Oxford and IBH Publishing Co., New Delhi)

Varshney RK, Glaszmann JC, Leung H, Ribaut JM (2010) More genomic resources for less- studied crops. Trends Biotechnol. 28:452-460.

Wahid A, Gelani S, Ashraf M, Foolad MR (2007) Heat tolerance in plants: An overview. Environ Exp Bot. 61:199223.

Zhou Y, Lam HM, Zhang J (2007) Inhibition of photosynthesis and energy dissipation induced by water and high light stresses in rice. J Exp Bot. 58:1207-1217. 